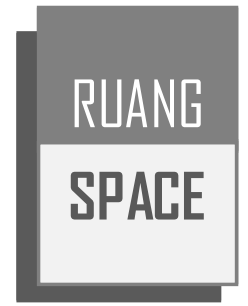

\title{
TRANSFORMASI PERMUKIMAN BALI AGA DI DESA PAKRAMAN TIMBRAH KABUPATEN KARANGASEM
}

\author{
Oleh: Ni Made Swanendri ${ }^{1}$, I Nyoman Susanta ${ }^{2}$
}

\begin{abstract}
This article studies the transformation of homes of Timbrah Settlement, a Bali Aga Community of Karangasem Regency. It focusses on two fundamental elements, namely spatial formation and built forms which are, by tradition, two unique features characterizing the built environment of Timbrah. These spatial elements symbolize complex socio-cultural systems of belief, subsistence, gender, knowledge, defend, time, territoriality, etc. In its development, the community has to inevitably interrelate with various congencies brought in by modernity - taking place globally, and other forces driven from within. Some observed consequences brought by these influences include (not limited to) modifications in value systems, way of people live their life, and demographic formations. This observation has constituted an inspiration to the conduct of this whole study, in which qualitative approaches were put into practice. Study findings demonstrate that almost all Timbrah homes (karang paumahan) have been transformed in one way or another. This condition is mainly due to a need for more living space, efficiency in spatial utilization, social status, self actualization, and to accommodate changes of inhabitants' lifestyle. The transformation of Timbrah homes has been carried out in a gradual manner, directed by a conscious understanding to maintain local knowledge and values, especially of those associated with the governance of space exist in both domestic and communal spheres. In consequence, attempts to keep Timbrah's identity as a unique Bali Aga community have been indirectly imposed on, at any given opportunity.
\end{abstract}

Kata kunci: spatial formation, traditional settlement, narrow lane, bale agung, Timbrah Community

\begin{abstract}
Abstrak
Artikel ini menampilkan hasil studi tentang transformasi permukiman Desa Timbrah yang merupakan salah satu permukiman Bali Aga di Kabupaten Karangasem. Studi ini difokuskan pada dua elemen fundamental yaitu pola spasial dan bentuk-bentuk terbangun dimana dua elemen dengan karakteristik unik unik tersebut secara tradisi membentuk permukiman Desa Timbrah. Elemen--elemen spasial ini melambangkan kompleksitas dari sistem sosio-budaya yang meliputi keyakinan, mata pencaharian, jenis kelamin, pengetahuan, pertahanan, waktu, territorial dan sebagainya. Dalam perkembangannya, masyarakat akan saling berhubungan dengan berbagai kongenitas yang dibawa oleh modernitas yang terjadi secara global serta kekuatan lain yang berasal dari dalam. Beberapa dampak yang teramati akibat pengaruh ini adalah termasuk (namun tidak terbatas pada) modifikasi dalam sistem nilai, cara orang menjalani hidup mereka, dan formasi demografis. Kondisi ini menjadi pendorong untuk melakukan kajian yang dilakukan dengan pendekatan kualitatif. Temuan-temuan dalam studi ini menunjukkan bahwa hampir semua rumah di Timbrah (karang paumahan) telah mengalami transformasi/perubahan dengan berbagai variasi. Kondisi ini terutama disebabkan oleh peningkatan kebutuhan ruang untuk hidup, efisiensi dalam pemanfaatan ruang, status sosial, aktualisasi diri serta akomodasi terhadap perubahan gaya hidup penghuni. Proses transformasi yang terjadi berjalan perlahan yang dilandasi oleh kesadaran untuk melestarikan pengetahuan dan nilai-nilai setempat. Ini menunjukkan bahwa secara tidak langsung upaya-upaya untuk menjaga keajegan identitas Timbrah sebagai komunitas Bali Aga yang unik senantiasa dilakukan disetiap kesempatan.
\end{abstract}

Kata kunci: pola spasial, permukiman tradisional, gang sempit, bale agung, masyarakat Timbrah

1 Program Studi Arsitektur, FT-Unud.

Email: nimadeswanendri@unud.ac.id

2 Program Studi Arsitektur, FT-Unud.

Email: susanta@unud.ac.id 


\section{Pendahuluan}

Eksistensi kehidupan manusia sangat erat dengan kebutuhan dasarnya yaitu pangan, sandang dan papan. Dalam tingkatan yang lebih luas, hal ini akan berkaitan dengan eksistensi dari sebuah permukiman yang harus dapat memenuhi kebutuhan manusia untuk hidup dengan aman dan bermartabat serta bersosialisasi dengan manusia lainnya. Permukiman sendiri dapat didefinisikan sebagai satu kesatuan yang terdiri dari lingkungan hunian yang terdiri atas lebih dari satu satuan perumahan yang mempunyai prasarana, sarana, utilitas umum, serta mempunyai penunjang kegiatan fungsi lain di kawasan perkotaan atau kawasan perdesaan. Dalam konteks Bali, pengertian desa secara mendasar dapat diklasifikasikan menjadi 2, yaitu desa dinas atau desa administratif dan desa pakraman. Penyebutan desa dinas mengacu pada entitas desa sebagai bagian dari pemerintahan formal, penyelenggara kegiatan administrasi pemerintahan dan hal lain yang bersifat kedinasan; sementara desa pakraman mengacu pada kelompok masyarakat tradisional dengan dasar ikatan adat istiadat (Suacana, 2011). Sementara para peneliti tentang Bali dan Majelis Pembina Lembaga Adat (MPLA) dengan berdasarkan tradisi dominan yang menjadi ciri, mengklasifikasikan desa pakraman kedalam tiga tipe (Swellengerebel, 1960; Danandjaja, 1980; MPLA, 1991 dan Reuter, 2005 dalam Suacana (2011), yaitu: Desa Bali Aga, Desa Apanage dan Desa Anyar. Desa Bali Aga ataupun Desa Bali Kuno memiliki keunikan-keunikan meliputi hampir setiap aspek kehidupan dari sistem kepercayaan, sistem budaya sampai pada perwujudan fisik rumah dan lingkungannnya termasuk pola spasial dan masih menampilkan unsur-unsur animisme. Secara mendasar dan implisit, prinsip yang mendasarinya adalah keharmonisan dengan alam, meniru alam semesta.

Pola-pola permukiman di Bali umumnya dipengaruhi oleh berbagai faktor diantaranya tata nilai ritual, sistem kepercayaan, kondisi, dan potensi alam serta ekonomi yang terdapat di permukiman tersebut. Masyarakat Bali sendiri dalam segenap aspek tata kehidupannya mengacu pada konsep tri hita karana (secara sederhana dapat iartikan sebagai tiga penyebab kebahagiaan) yang berintikan keharmonisan, yaitu keharmonisan dengan Tuhan selaku pencipta, keharmonisan dengan sesama manusia serta keharmonisan dengan alam. Karenanya, ketika membangun, pada dasarnya manusia membangun (arsitektur) meniru alam baik alam semesta (bhuana agung/ makrokosmos) maupun alam manusia (bhuana alit/mikrokosmos) dan berupaya untuk mencapai keseimbangan dan keharmonisan dengan lingkungan (pemanfaatan potensi setempat: sumber daya alam, manusia, pola fisik arsitektur).

Dalam sebuah proses apalagi proses kehidupan, terjadinya perubahan adalah sesuatu yang alami. Perubahan jumlah penduduk, profesi, kebiasaan/gaya hidup dan bahkan tata nilai dan sebagainya merupakan hal yang umum terjadi dalam suatu kelompok masyarakat termasuk dalam masyarakat desa bali aga. Perubahan-perubahan yang pada dasarnya terjadi secara alamiah semakin dipercepat dengan arus modernitas yang melanda hampir setiap belahan dunia. Selanjutnya, perubahan-perubahan juga dapat dilihat terjadi pada fisik permukimannya. Dalam konteks permukiman khususnya desa bali aga termasuk di Desa Timbrah yang menjadi lokasi studi, perubahan atau transformasi dapat ditemui dari unit terkecil (mikro) yaitu rumah tinggal sampai dengan tataran makro yang berkaitan dengan pola spasial atau tata ruang desa tersebut. 


\section{Metode Penelitian dan Lokasi Studi}

Mengacu pada Suryabrata (1997, pp. 15-18), penelitian yang dilakukan ini dari sisi lingkupnya termasuk dalam lingkup rancangan penelitian deskriptif. Secara umum, penelitian deskriftif sendiri atau yang dalam arti luas biasanya disebut dengan istilah penelitian survei mempunyai tujuan untuk membuat deskripsi (pencanderaan) dengan cara yang sistematis, faktual dan akurat menyangkut segala fakta-fakta pada daerah atau populasi tertentu. Dalam pelaksanaannya, pendekatan yang dipakai adalah pendekatan kualitatif mengingat dalam penelitian ini difokuskan pada kajian atau pemahaman terhadap faktorfaktor yang mempengaruhi transformasi permukiman yang terjadi di Desa Timbrah baik pada pada rumah tinggal maupun pola spasialnya.

Secara keseluruhan, teknik pengumpulan data yang dipergunakan dalam penelitian ini, meliputi: 1) Kajian Pustaka, dilakukan atas literatur-literatur yang terkait diantaranya hasilhasil penelitian serupa yang pernah dilakukan sebelumnya ataupun penelitian lain pada lokasi yang sama serta literatur-literatur lainnya yang terkait dengan sistem sosial budaya masyarakat Bali Aga, data-data fisik dan non fisik dari lokasi penelitian serta data-data sekunder lainnya. Hasil penelitian sebelumnya yang dilakukan oleh peneliti (Swanendri dan Setiada, 2015, 2016) akan menjadi sumber data utama dalam melakukan kajian pada penelitian ini; 2) Observasi, dilakukan untuk melengkapi data-data yang dirasa masih kurang. Observasi yang dilakukan berupa observasi non partisipatif dengan cara melakukan pencatatan, pengukuran, perekaman foto dan penggambaran sesuai dengan konteks penelitian; 3) Wawancara, dilakukan dengan model wawancara terencana-tidak terstruktur terhadap sumber informasi (kelihan, jero buyut, pemilik rumah) tentang hal-hal yang berkaitan dengan obyek dan konteks penelitian.

Penelitian dilakukan di Desa Timbrah yang masuk dalam lingkup wilayah administratif Desa Pertima, Kecamatan Karangasem, Kabupaten Karangasem sebagaimana terlihat pada Gambar 1. Desa ini terletak lebih kurang $7 \mathrm{~km}$ dari ibukota kecamatan dan kabupaten serta kurang lebih $85 \mathrm{~km}$ dari ibukota propinsi.

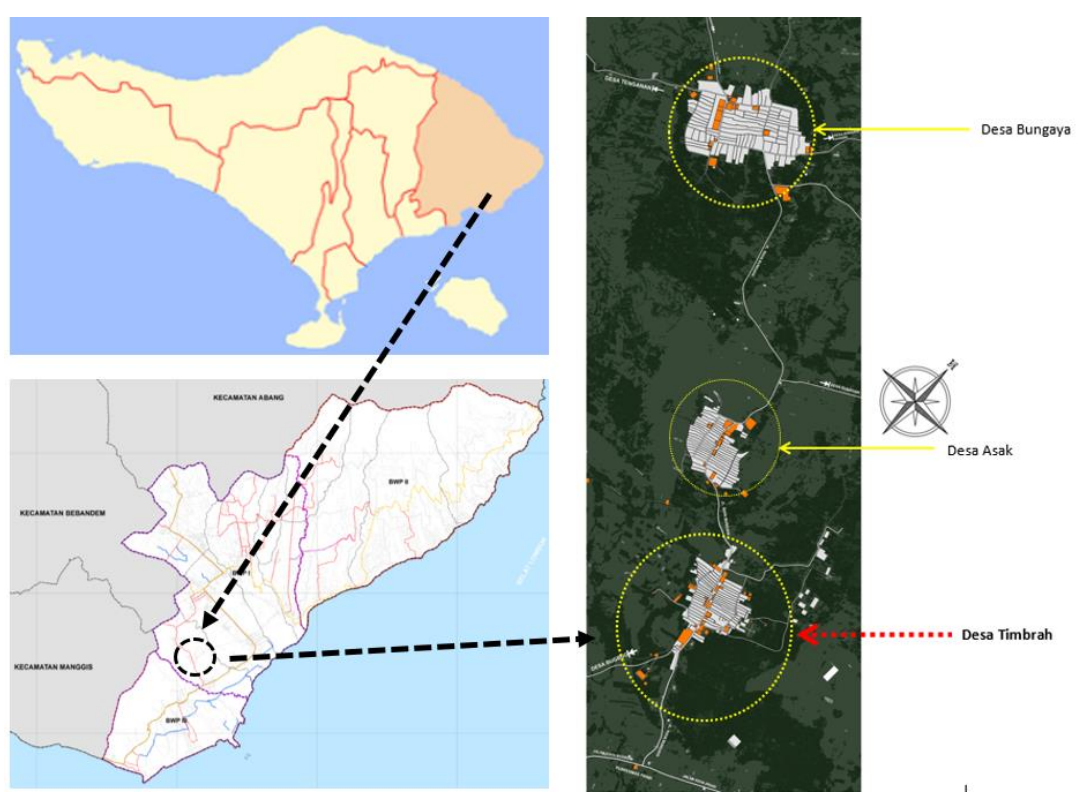

Gambar 1. Peta Lokasi Desa Timbrah

Sumber: Swanendri, 2017 \& karangasem.go.id 


\section{Permukiman dan Tradisi Bermukim}

Memahami permukiman tidak akan dapat lepas dari rumah sebagai unit terkecil. Dari sisi harfiah, rumah diartikan sebagai bangunan yang berfungsi sebagai tempat tinggal yang layak huni, sarana pembinaan keluarga, cerminan harkat dan martabat penghuninya serta aset bagi pemiliknya. Mengacu pada pengertian tersebut, jelas terlihat bahwa pemahaman rumah akan terkait tidak hanya dengan letak, ruang, bentuk atau hal-hal yang menyangkut fisiknya semata, namun juga dalam non fisik yang umumnya merupakan hal yang lebih kompleks seperti: status sosial, ekspresi dari eksistensi penghuninya, perkembangan kehidupan penghuninya, faktor ekonomis dan sebagainya. Pada sisi yang lain yaitu sisi fisik rumah itu sendiri, dinyatakan bahwa rumah bukanlah sesuatu yang sekali jadi, rumah senantiasa akan berkembang mengikuti dinamika penghuninya. Dalam tingkatan yang lebih luas, Altman (1989) menyebutkan bahwa rumah adalah refleksi dari hubungan antara kebudayaan dan lingkungan. Uraian-uraian tersebut mengindikasikan bahwa sebuah rumah pada dasarnya merupakan sesuatu yang bersifat dinamis dan secara alamiah akan senantiasa berkembang, senantiasa berubah, senantiasa bertransformasi sesuai dinamika yang ada.

Setelah rumah, dalam cakupan yang lebih luas kita mengenal permukiman. Mengacu pada UU No. 1 Tahun 2011 tentang Perumahan dan Kawasan Permukiman, pengertian kawasan permukiman, lingkungan hunian dan permukiman adalah sebagai berikut:

- Kawasan Permukiman adalah bagian dari lingkungan hidup di luar kawasan lindung, baik berupa kawasan perkotaan maupun perdesaan, yang berfungsi sebagai lingkungan tempat tinggal atau lingkungan hunian dan tempat kegiatan yang mendukung perikehidupan dan penghidupan.

- Lingkungan hunian adalah bagian dari kawasan permukiman yang terdiri atas lebih dari satu satuan permukiman

- Permukiman adalah bagian dari lingkungan hunian yang terdiri atas lebih dari satu satuan perumahan yang mempunyai prasarana, sarana, utilitas umum, serta mempunyai penunjang kegiatan fungsi lain di kawasan perkotaan atau kawasan perdesaan.

Mengkhusus pada masyarakat Bali Aga, konsepsi permukiman pada umumnya ditata berdasarkan beberapa pertimbangan, seperti berdasarkan hirarki nilai tempat yang disusun berdasarkan konsep luan teben. Posisi luan mengacu pada arah kaja/gunung/munduk atau tempat yang lebih tinggi. Posisi luan diberi nilai lebih tinggi dari posisi teben dan diperuntukkan untuk tempat pemujaan masyarakat pada tingkat desa.

\section{Konsep Rumah Bali}

Secara umum rumah tradisional Bali berlatar belakang penyelarasan hubungan antara manusia dan alam dimana didalamnya akan terkandung aspek nilai budaya, aspek kepercayaan serta aspek status sosial (Patra, 1992: 23-26). Konseptual perancangan rumah seperti halnya konsep perancangan arsitektur tradisional pada umumnya, didasarkan pada tata nilai ruang yang dibentuk oleh sumbu kosmos (bhur, bwah, swah), sumbu ritual (kajakelod) dan sumbu natural (kangin - kauh).

Secara umum, unsur-unsur hunian tradisional Bali meliputi (Departemen Pendidikan dan Kebudayaan, 1985: 35-40; Patra, 1992): 
1. Penyengker, merupakan batas kepemilikan sebidang tanah di mana berkumpul unsurunsur fisik pembentuk hunian beserta penghuninya.

2. Pekarangan/tapak hunian, sebidang tanah kosong tempat diletakkannya gugus massa dalam pola tertentu yang memiliki orientasi kaja-kelod dan kangin-kauh (gunung-laut dan matahari terbit-terbenam), memunculkan pembagian sembilan tata nilai daerah/zoning yang disebut dengan Sanga Mandala. Pada areal tengah terdapat natah yang memiliki fungsi serbaguna, sebagai orientasi pengikat gugus bangunan, tempat upacara, lintasan kegiatan, tempat menjemur hasil bumi, menerima tamu, dan lain-lain. Natah merupakan ruang tanpa atap yang dibentuk oleh gugus bangunan yaitu paon, bale dauh, bale dangin, bale meten, jineng, dan sanggah. Pada setiap pekarangan memiliki tiga jenis natah, yaitu natah paon terletak di depan dapur dengan nilai nista/profan, natah umah di pusat pekarangan dengan nilai madya, dan natah merajan/sanggah, tempat suci keluarga dengan nilai utama.

3. Bale, merupakan gugus bangunan dalam pekarangan, meliputi a) sanggah/pemerajan untuk tempat suci/sembahyang keluarga yang terletak di bagian timur laut pekarangan; b) bale daja (meten) yang terletak di bagian utara untuk tempat tidur anak gadis/wanita, atau disebut juga bale gedong bila difungsikan sebagai tempat penyimpanan bendabenda pusaka atau benda sakral; c) bale dauh yang terletak di bagian barat, bersebelahan dengan paon, untuk tempat tidur orang tua di malam hari, sedangkan di siang hari untuk menerima tamu; d) bale dangin/bale sumanggen di bagian timur, untuk tempat upacara yang paling sakral, sedangkan pada malam hari digunakan untuk tempat tidur anak lakilaki; e) bale delod di sisi selatan; f) paon untuk kegiatan memasak, dekat dengan pintu pekarangan; g) lumbung/jineng untuk menyimpan padi dan hasil bumi lainnya.

Sementara bangunan yang berkembang dalam arsitektur Bali Aga pada umumnya bangunan yang kecil, masih sederhana dan tidak banyak menggunakan ornamen. Bangunan ini menggunakan kolom kayu untuk menyangga atap dan penamaan bangunan dilakukan berdasarkan jumlah tiang kayu yang digunakan.

\section{Transformasi Permukiman}

Secara leksikal, transformasi diartikan sebagai perubahan rupa, perubahan bentuk, perubahan sifat, perubahan fungsi dan sebagainya (Poerwadarminta, 1982). Transformasi juga terjadi pada permukiman, baik pada rumah tinggalnya maupun pada pola spasialnya. Pada bagian sebelumnya telah dijelaskan bahwa rumah bukanlah sesuatu yang sekali jadi, rumah akan senantiasa berkembang mengikuti dinamika penghuninya dan rumah adalah refleksi dari hubungan antara kebudayaan dan lingkungan (Altman, 1989). Dengan bertolak pada hal tersebut, terjadinya transformasi pada rumah tinggal dan tata ruang/pola spasial suatu permukiman permukiman merupakan sesuatu yang pasti terjadi, yang berbeda adalah tingkat perubahan yang terjadi dan kecepatan waktu dari transformasi tersebut.

Adanya transformasi hunian pada suatu kawasan permukiman diduga disebabkan oleh adanya pengaruh kuat dari perubahan-perubahan yang terjadi dalam tatanan budaya masyarakat, adanya inkulturasi, akulturasi, proses dialog, hingga sintesis budaya yang muncul dalam kelompok masyarakat dapat menyebabkan pergeseran maupun perkembangan nilai-nilai suatu kebudayaan atau interaksi sosial dari masyarakat tertentu 
(Oetama, 1989; Sachari \& Sunarya, 2001 dalam Sesotyaningtyas $d k k$. (2015, p. 117). Terkait dengan proses perubahan yang mungkin terjadi, Rapoport menyatakan bahwa perubahan cenderung terjadi pada peripheral elements dibandingkan dengan core elements (Rapoport, 1983, p. 261). Lebih lanjut, jika dilihat dari prosesnya, transformasi dapat berlangsung sebagai berikut (Alexander, 1987) :

- Proses transformasi berjalan secara perlahan

- Proses awal dan akhirnya tidak dapat diketahui atau diduga dan tergantung pada latar belakangnya

- Proses transformasi berlangsung secara komprehensif dan berkesinambungan

- Proses transformasi memiliki kaitan erat dengan sistem nilai yang ada

Sementara itu, transformasi hunian dipengaruhi oleh dua faktor (Habraken, 1976:39-41 dalam Swanendri \& Dewi (2010, p. 18). Pertama, faktor internal yaitu faktor-faktor yang ada dalam diri seseorang berupa penambahan anggota keluarga, perkembangan kebutuhan, dan perubahan gaya hidup. Kedua, faktor eksternal yaitu faktor-faktor yang dapat mempengaruhi kepribadian seseorang yang berasal dari luar dirinya, seperti latar belakang budaya dan latar belakang pendidikan. Faktor-faktor yang mendorong penghuni melakukan transformasi terhadap huniannya adalah sebagai berikut:

a. Kebutuhan identitas diri

Pada dasarnya orang ingin dikenal dan ingin memperkenalkan diri terhadap lingkungan komunitasnya. Kebutuhan ini dapat kita lihat dalam hal pemilihan sandang, perabotan, kendaraan, dan barang-barang lainnya. Begitu juga pada saat penghuni merubah atau mengembangkan rumah yang seringkali pula dipergunakan sebagai alat untuk mengekspresikan diri.

b. Perubahan gaya hidup

Perubahan gaya hidup disebabkan oleh perubahan struktur dalam masyarakat, pengaruh kontak dengan budaya lain ataupun munculnya pandangan baru tentang manusia dan lingkungan sehingga mempengaruhi gaya hidup seseorang.

c. Penggunaan teknologi baru

Penemuan-penemuan baru dalam bidang teknologi menyebabkan timbulnya perasaan ingin mengikuti mode. Komponen bangunan yang masih dapat terpakai secara teknis kemudian diganti supaya jangan dianggap ketinggalan jaman, hal ini didukung pula dengan adanya produksi massal yang harganya relatif lebih murah. Atau karena umur material yang dipakai dalam suatu rumah sudah rusak sehingga membutuhkan penggantian.

d. Pertambahan anggota keluarga

Bertambahnya penghuni dalam suatu keluarga akan mempengaruhi penambahan jumlah ruangan dan perabotan yang dibutuhkan oleh penghuni dalam beraktifitas sehari-hari. Walaupun demikian dorongan untuk memiliki hunian yang sesuai dengan kebutuhan dibatasi oleh faktor keterbatasan kondisi hunian tradisional.

\section{Permukiman di Desa Timbrah}

Desa Timbrah terletak pada jalur utama Desa Perasi - Bebandem dimana jaringan jalan ini melintas di tengah-tengah desa. Fasilitas-fasilitas komunal utama terletak di bagian tengah 
desa pada sekitar jaringan jalan utama ini. Aksis dan ruang komunal utama tersebut terlihat sebagai inti dan sekaligus pengikat dari pola spasial permukiman Desa Timbrah tersebut. Aksis dan ruang komunal utama tersebut kemudian dikelilingi oleh area perumahan dimana akses menuju karang paumahan (gang) berada pada posisi tegak lurus terhadap jalan utama atau melintang dengan arah timur barat. Pola ini terlihat dengan sangat jelas dan tetap dipertahankan, walau pada perkembangan area perumahan yang baru, pola ini terlihat mengabur, walau pada beberapa bagian masih coba untuk diikuti.

Secara tradisional rumah-rumah/karang paumahan yang ada di Desa Timbrah diakses dari arah selatan, jadi gang yang melintang timur barat hanya melayani satu sisi saja. Dengan demikian, pintu masuk pekarangan/pemesuan akan terletak pada kelod kauh/barat daya dan tidak ada rumah dalam satu gang yang berhadap-hadapan. Kondisi ini juga dapat menjadi salah satu justifikasi kenapa lebar gang-gang yang ada di seputaran desa mempunyai lebar yang minimal.

Di dalam pekarangan, tata nilai yang dianut sama dengan tata nilai ruang yang dianut oleh daerah atau desa-desa di Bali pada umumnya. Arah kaja kangin menjadi area yang paling utama dan bangunan sanggah sebagai area pemujaan ditempatkan pada bagian ini. Di Desa Timbrah sanggah tidak hanya menjadi tempat untuk melakukan pemujaan tapi juga dapat menjadi akses bagi orang yang diamanatkan tugas suci sebagai taksu. Seorang anak perempuan yang belum akil balik, jika ditunjuk atau mengemban tugas sebagai taksu, wajib ketika masuk dan keluar dari kamar tidurnya melalui natar sanggah. Bagian timur dari pekarangan menjadi tempat dari bale dangin yang dari sisi bentuknya dapat bervariasi mulai dari bale gede (bale sakeroras), bale sakenem maupun meten. Pilihan ini ditentukan atas besar kecilnya sikut pekarangan dan juga kondisi ekonomi dari pemilik rumah. Umumnya yang memiliki bale gede adalah orang-orang menempati pekarangan dengan sikut yang lebih luas serta memiliki kemampuan ekonomi yang lebih dari cukup pada saat itu. Pada bagian utara pekarangan akan ditempatkan meten atau sakenem sebagai area untuk tidur dari penghui rumah. Sementara pada sisi selatan dari arah timur ke barat berjajar kandang, paon dan kamar mandi. Jika area masih memungkinkan, pada bagian barat akan ditempatkan lumbung atau bale sakepat sebagai area serbaguna.

\section{Diskusi}

Rumah merupakan salah satu kebutuhan pokok bagi manusia dalam kehidupan individu dan sosialnya. Kenyataan menunjukkan bahwa (bentuk fisik) rumah bukanlah sesuatu yang statis dalam artian dibangun sekali dan selamanya seperti itu. Rumah sejatinya mempunyai sifat yang dinamis, ia bukalah sesuatu yang bersifat sekali jadi, sekali terbentuk; ia akan berkembang sesuai dengan perkembangan penghuninya. Dengan kata lain rumah juga akan mengalami proses transformasi atau perubahan baik bentuk, fungsi dan sebagainya. Yang paling nyata tentunya jika transformasi ini terjadi pada bentuk atau berdampak pada perubahan bentuk rumah. Dari berbagai studi yang dilakukan diketahui bahwa proses ini terjadi di hampir seluruh tipe rumah baik yang berada di perkotaan ataupun pedesaan, baik yang berada di dalam konteks permukiman modern maupun tradisional. Yang berbeda hanyalah kompleksitas dari perbubahan tersebut serta laju kecepatan perubahan tersebut. 
Pada lokasi studi di Desa Timbrah, rumah - rumah yang ada umumnya menempati area pekarangan/persil yang dapat dikatakan relatif lebih sempit jika dibandingkan dengan pekarangan/persil rumah - rumah tradisional di desa lain terutama pada desa apenage (Bali dataran). Sebagian besar pekarangannya berkisar antara 150-200 meter persegi dan hampir semua pekarangan yang ada menghadap atau diakses dari sisi selatan, perbedaan hanya terjadi pada sebagian kecil pekarangan - pekarangan yang berada pada wilayah pengembangan dan beberapa rumah yang berada di dekat akses jalan besar (jalan lingkar desa) dengan pertimbangan pengadaan akses bagi kendaraan roda empat (Gambar 2., bagian A). Sementara, rumah yang berada pada bagian core desa atau sepanjang akses utama cenderung masih mempertahankan akses asli yaitu dari sisi selatan pekarangan (Gambar 2., bagian B) walau sebagian besar rumah - rumah yang berada di sepanjang akses utama ini telah berkembang tidak semata menjadi tempat tinggal semata namun didalamnya telah berkembang HBE (home based enterprices) yang didominasi oleh jasa perdagangan baik berupa toko maupun warung (Gambar 3). Dari pengamatan yang dilakukan sebagian besar toko atau warung ini juga mempunyai akses tambahan yaitu adanya akses atau pintu yang menghubungkan antara toko atau warung dengan bagian rumah yang berfungsi sebagai tempat tinggal. Namun akses ini hanya dipergunakan untuk mendukung kelancaran aktivitas ekonomi yang menjadi bagian dari rumah dan tidak menggantikan akses utama yang berada di sisi selatan pekarangan.

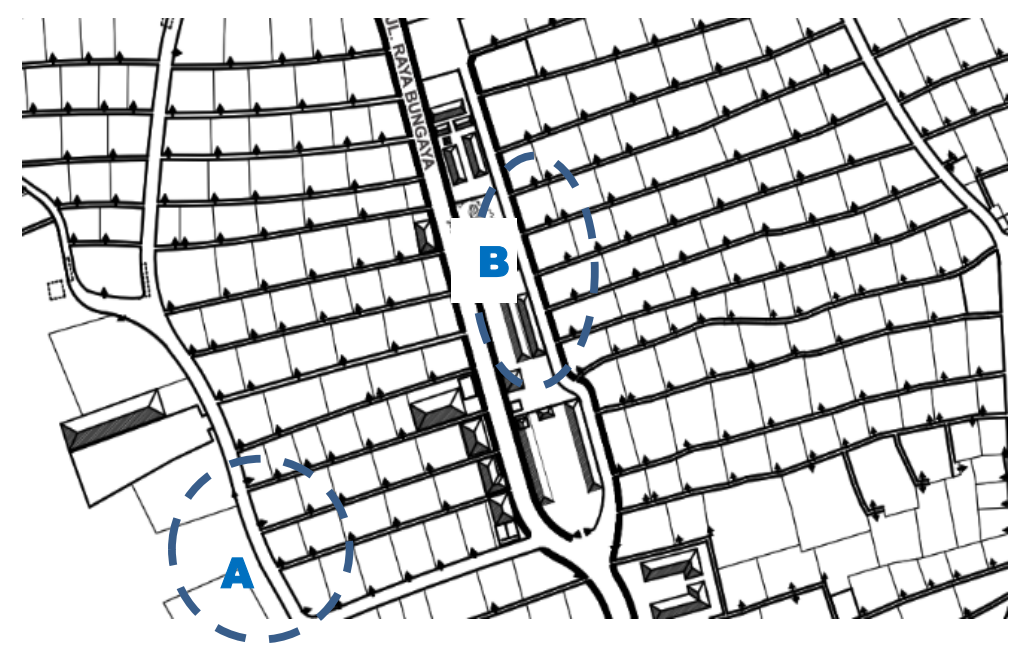

Gambar 2. Akses pada Pekarangan

(bagian A: akses berubah; bagian B: akses tetap walau fungsi rumah berkembang)
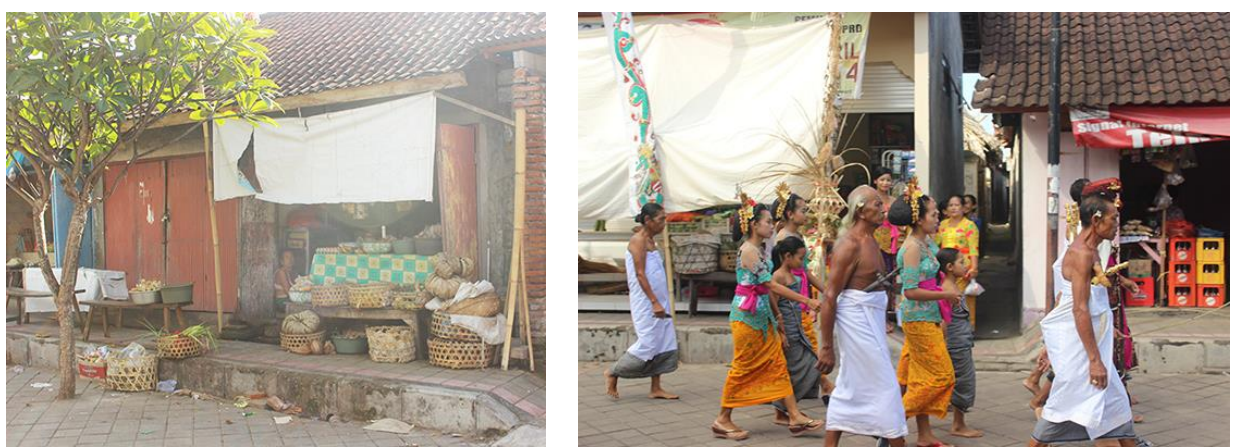

Gambar 3. Pengembangan aktivitas HBE pada rumah - rumah di sepanjang core desa / jalan utama

Sumber: Observasi, 2016-2017 
Berkembangnya HBE berupa jasa perdangangan tidak ditemui pada akses - akses yang menuju ke rumah-rumah. Sempitnya akses atau gang yang menuju ke masing - masing rumah serta terbatasnya area pekarangan menjadi faktor yang menghambat perkembangan ini. Pengembangan jenis HBE lain di dalam rumah jarang ditemui, berapa ada yang melakukan kegiatan usaha berupa pembuatan makanan kecil dan menganyam, namun dalam skala kecil dan terkadang terputus serta tidak membawa dampak signifikan pada perubahan bentuk rumah.

Dari sisi pemakaian bahan bangunan, seperti yang terlihat pada Gambar 4., pada awalnya rumah - rumah di Desa Timbrah mempergunakan bahan bangunan berupa tatal atau tanah polpolan, bata mentah (tidak dibakar) dan bambu pada bagian dinding serta alang - alang pada bagian atap. Masih dapat ditemui beberapa bangunan yang memakai material ini terutama pada bangunan - bangunan yang belum dapat direhab/diperbaiki oleh penghuninya karena alasan ekonomi. Sesuai dengan perkembangan teknologi bahan bangunan dan trend, rumah - rumah yang ada saat ini didominasi oleh pemakaian material berupa batako, bata, batu tabas dan paras pada bagian dinding serta genteng pada bagian atap (Gambar 5).
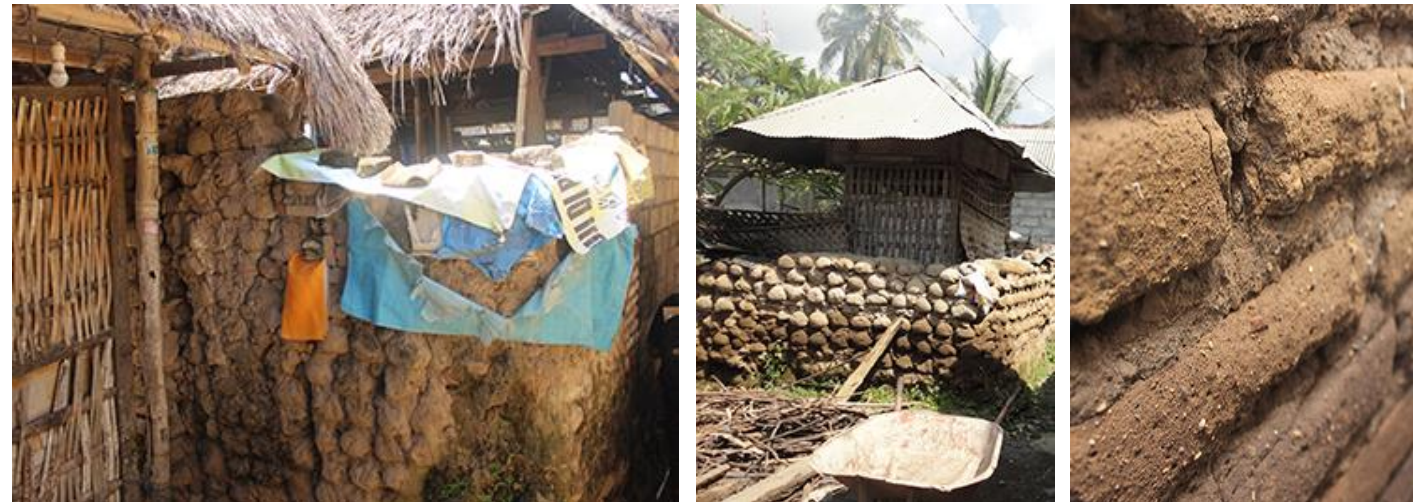

Gambar 4. Tatal (tanah polpolan), Bata Mentah dan Bambu (merupakan material bagunan yang dipegunakan pada awal pembangunan)

Sumber: Observasi, 2017
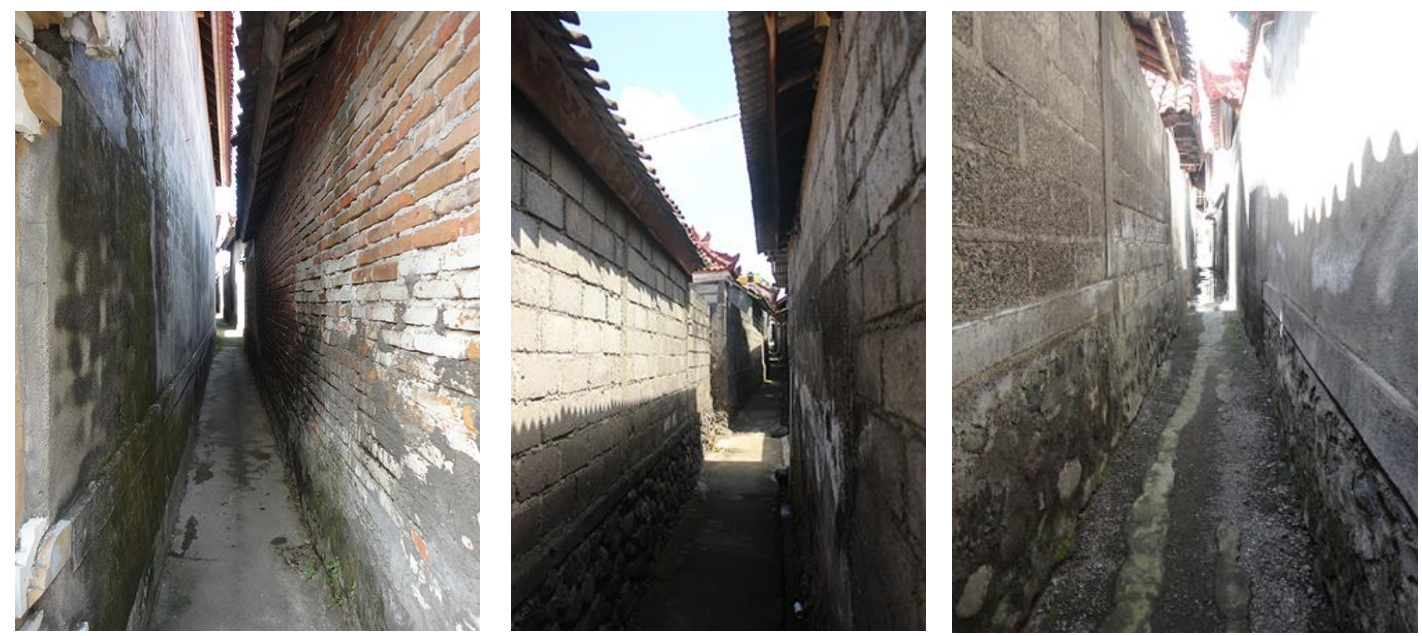

Gambar 5. Bata, Batako, Batu Tabas, Paras

(merupakan material bagunan yang lazim dipergunakan saat ini)

Sumber: Observasi, 2017 
Eksistensi bangunan - bangunan rumah (unit - unit bangunan yang berada dalam pekarangan rumah tinggal) yang masih cederung tampil dengan tampilan asli (masih asli, belum mengalami perubahan atau perubahannya sangat sedikit) baik dari sisi tata ruang maupun penggunaan meterial, umumnya karena faktor ekonomi pemiliknya yang belum mampu untuk melakukan perbaikan atau renovasi. Jika dilakukan perubahan, pemilik cenderung untk mengikuti syte kekinian baik dari sisi penataan ruang maupun style dan penggunaan bahan bangunan. Kondisi ini diungkapkan oleh pemilik - pemilik rumah yang masih memiliki 'bangunan asli'. Selain itu, sangatlah sulit untuk menemukan rumah (unit unit bangunan yang berada dalam pekarangan rumah tinggal) yang masih asli serta melihat dari kondisi lapangan secara keseluruhan di mana bangunan - bangunan yang ada didominasi oleh bentuk - bentuk sesuai style kekinian.

Perubahan yang dilakukan oleh masyarakat atas huniannya umumnya didorong oleh tidak ketidakmampuan bangunan lama dalam mendukung dinamika penghuninya terutama dari sisi kebutuhan akan penambahan jumlah ruang dan tuntutan privacy yang mengiringinya, kebutuhan akan ruang - ruang dalam rumah yang lebih kompak dan sesuai dengan tuntunan gaya hidup, serta pemenuhan unsur kebersihan, kerapian dan kesehatan yang (dianggap) tidak dapat dipenuhi oleh bangunan lama. Karenanya ketika melakukan renovasi atau perbaikan, masyarakat cenderung meninggalkan bentuk-bentuk tradisi. Di sisi lain, walau desa ini tergolong desa tua yang sangat taat pada pelaksanaan tradisi / ritual adat, dalam pemanfaatan ruang bagi kegiatan ritual keagamaan yang berlangsung di dalam karang paumahan dianut konsep fleksibilitas. Hal ini juga menjadikan pemilik menjadi lebih leluasa untuk melakukan perubahan atas rumahnya. Gambaran hunian seperti yang ditampilkan pada Gambar 6 adalah contoh rumah yang didalamnya masih mempertahankan sebagian bentuk aslinya, sementara Gambar 7 adalah contoh dari penataan ruang dari rumah - rumah yang telah mengalami perubahan total di mana kondisi seperti inilah yang saat ini mendominasi di Desa Timbrah

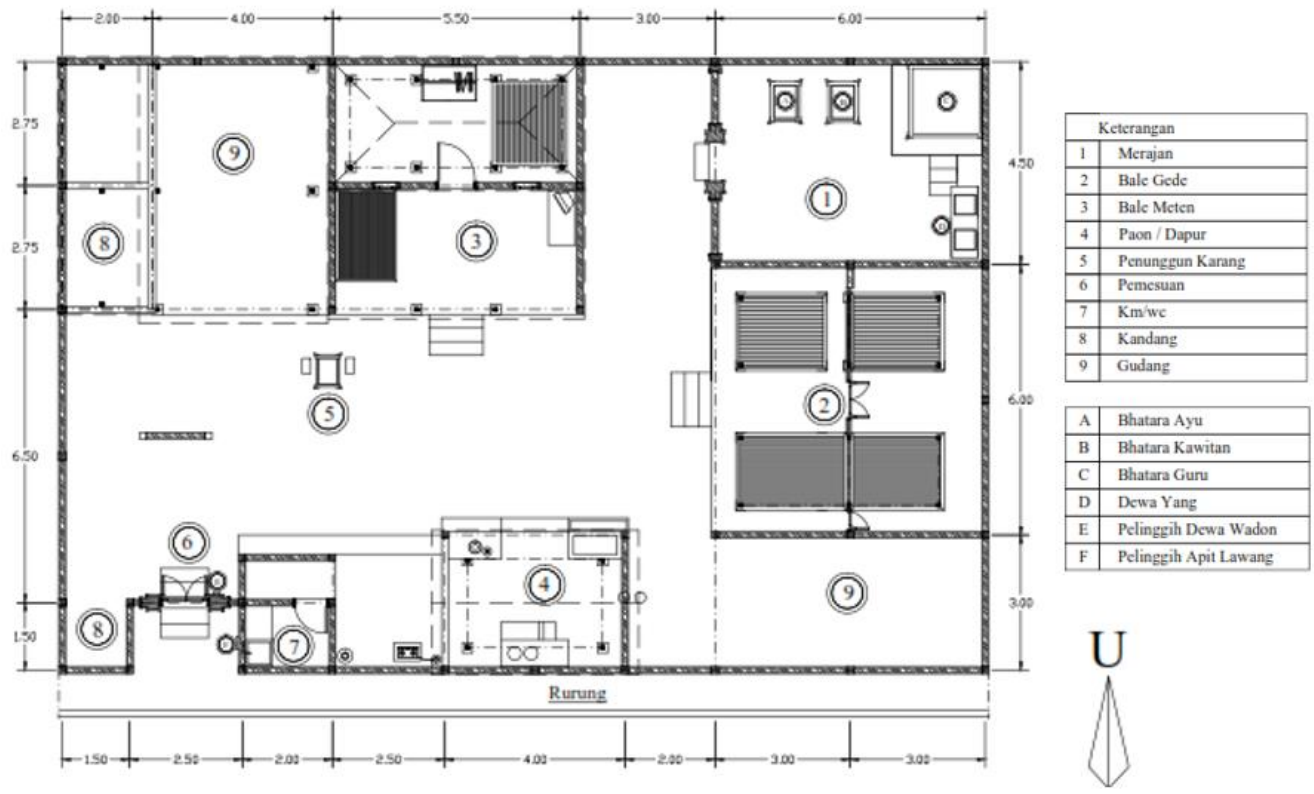

Gambar 6. Rumah yang masih Mempertahankan Meten dan Bale Gede 


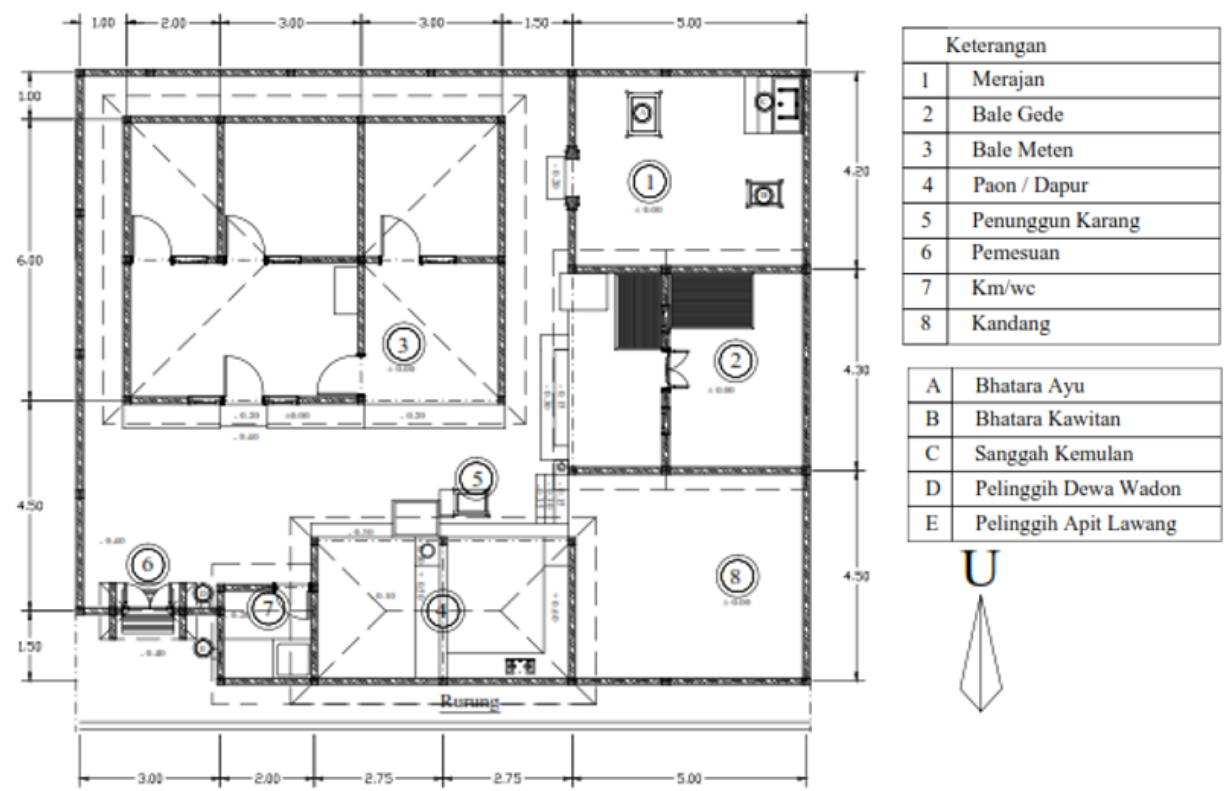

Gambar 7. Rumah yang Mengalami Perubahan

Telah dinyatakan di atas bahwa rumah bukanlah sesuatu yang statis. Ketika terjadi perubahan atau penambahan anggota keluarga, jumlah ruangan dan kelengkapan dalam rumah juga dituntut bertambah. Akan timbul penambahan ruang tidur baru atau bahkan unit bangunan dalam pekarangan, garase dalam pekarangan rumah dan lain sebagainya. Ketika terjadi perkembangan dalam teknologi bahan yang melahirkan bahan - bahan bangunan yang lebih variatif (warana, motif, ukuran) serta lebih murah dan lebih mudah dalam perawatan, pemilik tentu ingin mencobanya.

Selain sebagai kebutuhan pokok, rumah secara tradisional merupakan salah satu sarana untuk ekspresi diri dan menunjukkan identitas atau status sosial. Ketika gaya hidup berubah, rumah pun berubah. Kehadiran sepeda motor di hampir setiap rumah tangga telah mengakibatkan perubahan pada angkul - angkul. Pada bagian bawah yang aslinya berupa undag / step berubah menjadi ramp dan ini pasti dilakukan ketika sepeda motor sebagai bagian dari gaya hidup modern hadir di dalam rumah. Namun demikian, pada gang - gang yang paling sempit, sepeda motor tidak dapat masuk sehingga angkul -angkul yang ada cenderung dipertahankan. Kondisi eksisting yang ada saat ini terkait bentuk asli dari angkul - angkul dan perubahannya disajikan pada Gambar 8.
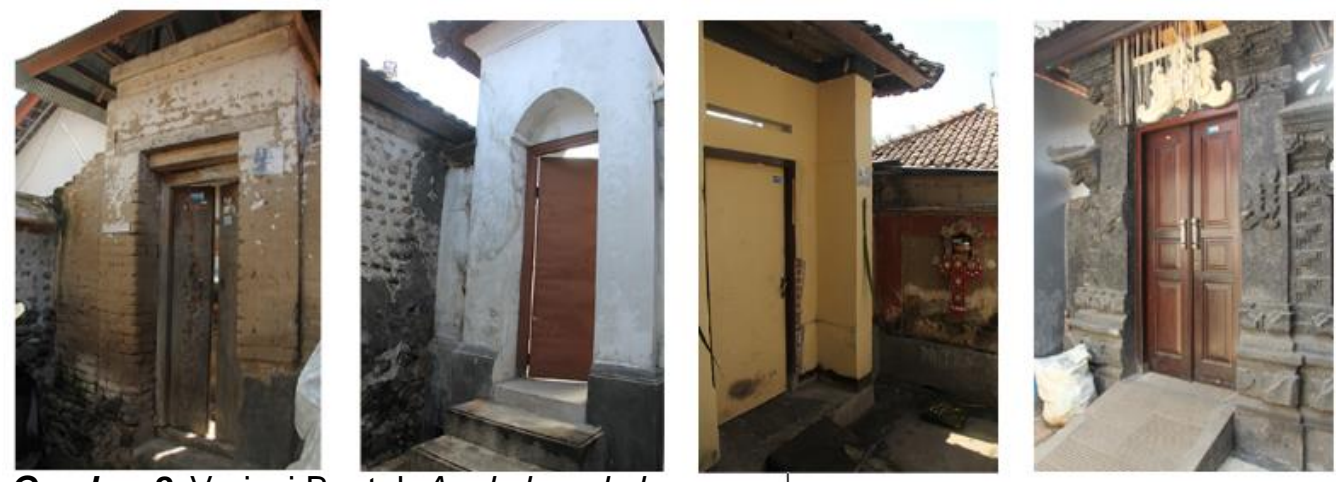

Gambar 8. Variasi Bentuk Angkul-angkul

Sumber: Observasi, 2017 
Perubahan yang lebih signifikan terjadi pada rumah - rumah yang penghuninya memiliki kendaraan roda empat dan kebetulan posisinya berada di dekat jalan lingkar (sisi barat dan sisi timur desa), bahkan merubah posisi akses rumah menjadi dari arah jalan tersebut, padahal secara tradisi yang kuat dipegang dan menjadi ciri khas yang kuat dari desa ini adalah akses masuk ke pekarangan adalah dari arah selatan / barat daya (kelod kauh).

Hal lain yang tidak kalah kuat mendorong terjadinya transformasi pada rumah - rumah di Desa Timbrah adalah kebutuhan ekspresi diri. Hal ini terutama diasosiasikan dengan pemakaian bahan - bahan bangunan secara umum memberikan pemahaman mahal dan berkelas. Mulai bermunculan penggunaan paras, bata gosok yang nota bene bukan merupakan bahan lokal baik asal materialnya maupun tenaga yang terlibat dalam pemasangannya.

Pada tingkat yang lebih makro, telah disampaikan bahwa pola spasial permukiman pada Desa Pakraman Timbrah yang merupakan salah satu desa tua atau Desa Bali Aga yang ada di Kabupaten Karangasem dibentuk dari aksis utama yang membujur utara - selatan sebagai inti dan pengikat dari pola spasial keseluruhan. Pada aksis utama ini terdapat fasilitasfasilitas komunal utama seperti Bale Agung, Bale Pauman, Pura Panti Kaler, Pura Panti Tengah, Pura Wayah dan sebagainya yang memegang peranan penting dalam pelaksanaan tradisi dan kehidupan sosial masyarakat yang masih sangat kental dengan nuansa tradisi Bali Aga. Sentra aktivitas sosial budaya masyarakat memang terpusat pada fasilitas-fasiltas komunal ini. Fasilitas-fasilitas utama ini pada dasarnya terletak membujur di tengah-tengah desa sehingga cenderung mudah dijangkau dari segara arah penjuru desa. Sebagai suatu pola, posisi fasilitas-fasilitas komunal utama ini yang terletak di tengah-tengah wilayah desa diperkuat dengan posisi karang paumahan sebagai bagian dominan dari suatu permukiman yang terletak mengelilingi (atau disini lebih tepatnya dapat dikatakan mengapit) pada sisi kiri dan kanan (timur dan barat) dari fasilitas komunal utama ini.

Dalam perkembangan selanjutnya terkait dengan perkembangan infrastuktur modern, aksis utama desa ini bekembang menjadi jalur utama antar desa sehingga terlihat jalan utama desa seakan-akan membelah desa. Bagian inti ini pada dasarnya merupakan bagian yang disakralkan oleh masyarakat walau tidak ada pemisahan yang signifikan antara bagian dengan bagian perumahan. Pemisahan hanya dilakukan dengan penambahan trotoar pada batas yang ditetapkan. Jalan akses di sekeliling fasilitas konumal utama ini memegang peranan sangat penting ketika dilaksanakan upacara-upacara besar seperti ngusaba sumbu misalnya, mengingat jalan ini akan menjadi jalur prosesi utama dari rangkaian upacara tersebut. Karenanya kondisi aksis utama ini tetag ajeg dan terjaga sampai sekarang. Seperti halnya desa lain pada umumnya, jika tidak dipergunakan untuk upacara, bagian inti dari aksis utama permukiman (kecuai jeroan bale agung dan jeroan pura) ini dapat digunakan oleh masyarakat untuk aktivitas sosial dan ekonomi keseharian seperti bercengkama, jualan, dan sebagainya dalam batas-batas yang disepakati.

Pola permukiman Desa Pakraman Timbrah dibentuk oleh letak dan akses karang paumahan yang sangat khas dan masih bertahan sampai sekarang. Seperti halnya bagian inti dari permukiman yang berbentuk linier, pola yang dibentuk karang paumahan pada desa ini juga berbentuk linier yang sangat jelas dengan arah yang tegak lurus terhadap aksis utama. Pola 
linier ini terbentuk dengan pola yang jelas dikarenakan satu gang hanya menjadi akses bagi satu jalur perumahan dan semua gang pada wilayah inti karang paumahan (ditandai/dibatasi dengan jalan melingkar desa) membujur dengan arah timur - barat. Dan jika ditelusuri secara lebih teliti, awalnya pada karang paumahan inti semua akses menuju rumah adalah dari gang walau rumah tersebut berada di sebelah akses utama ataupun jalan lingkar (kondisi jalan lebih lebar). Pola ini tetap bertahan karena beberapa kearifan lokal ketika ruang desa terbentuk serta tradisi bemukim yang masih dijalankan sampai sekarang.

Tidak ada sumber yang dapat menjelaskan secara pasti kenapa akses menuju karang paumahan (gang) yang terdapat pada desa ini sangat sempit dan terkesan tidak nyaman. Namun, jika dilihat dari konsep pengembangan perumahan dan permukiman, kondisi akses menjadi salah satu instrumen penting dalam mempertahankan konsep awal dari pengadaan suatu perumahan dan permukiman. Akses yang sempit seperti ini, secara tidak langsung akan meredam atau menghalangi perubahan yang disebabkan dinamika kehidupan modern terutama terkait dengan kepemilikan kendaraan, misalnya membuat garasi mobil. Kondisi gang yang sempit tentunya tidak memungkinkan, jangankan untuk akses kendaraan roda empat, pada bebarapa bagian bahkan kendaaran roda dua juga sulit untuk masuk gang. Kondisi yang kontras dapat dilihat pada karang paumahan yang berada di pinggir jalan lingkar, pada beberapa karang paumahan inti dan sebagian yang berada pada area perumahan pengembangan, dimana telah dilakukan perubahan orientasi yaitu merubah orientasi ke arah jalan utama atau jalan lingkar (jalan yang lebih lebar) yang dimotivasi terutama oleh adanya kebutuhan untuk memasukkan kendaraan roda empat ke dalam pekarangan.

Selain hal tersebut, satu hal yang masih dipegang dan dijalankan secara teguh adalah tradisi bahwa memasuki karang paumahan harus dari sisi kelod/selatan terutama dari arah kelod kauh/barat daya. Tradisi dan kearifan ini telah memberikan kontribusi yang besar pada pola permukiman. Pada area inti karang paumahan, tidak ada karang paumahan yang menempel pada arah utara - selatan. Secara otomatis, pengaturan seperti ini juga akan menghidarkan karang paumahan yang ada di desa ini terhadap beberapa pantangan perumahan adati seperti: numbak rurung, karang apitan, ngeluaning pura, karang lingkuhan, karang negen dan celedu nginyah.

Dari pemaparan pada bagian sebelumnya diketahui bahwa proses transformasi yang secara esensi bermakna perubahan merupakan sesuatu yang tidak dapat dihindarkan pada permukiman Bali Aga di Desa Pakraman Timbrah baik pada rumah tinggalnya maupun pada pola spasialnya. Transformasi yang terjadi, berkembang seiring dengan dinamika penghuninya, mengingat keduanya merupakan refeleksi antara manusia dengan lingkungannya. Pengaruh terbesar berasal dari perubahan - perubahan dalam tatanan sosial budaya masyarakat. Pada lokasi studi, peningkatan kebutuhan akan ruang akibat berkembangnya jumlah anggota keluarga termasuk berkembangnya keluarga - keluarga baru serta perubahan gaya hidup yang mengarah pada pola keluarga - keluarga inti, mengakibatkan persil perumahan semakin bertambah dari lot semula. Pertimbangan kemudahan akses dan perlunya akses bagi kendaraan, telah mendorong rumah - rumah yang berada dekat dengan jalan lain selain gang yang membujur barat - timur merubah orientasi rumahnya dari ke arah selatan menjadi ke arah yang dimensinya lebih lebar. Perkembangan 
di bidang material juga telah menjadi katalis terjadinya proses transformasi pada bangunan rumah tinggal. Jika dilihat dari dari kondisi eksisting bahwa masih cukup mudah untuk mengenali pola - pola spasial asli, difahami bahwa proses transformasinya berjalan secara perlahan dengan tetap mereferensi pada sistem nilai atau kearifan - kearifan lokal yang ada.

Pembahasan di atas memperkuat apa yang telah diungkapkan oleh Rapoport bahwa dalam proses pembentukan lingkungan binaan dan perubahan yang terjadi terhadapnya, faktor sosial budaya merupakan faktor pengaruh utama/primer sementara faktor iklim, metode konstruksi, ketersediaan bahan dan teknologi merupakan faktor primer. Hal ini diperkuat dengan kondisi fisik desa dimana topografi Desa Pekraman Timbrah terutama pada bagian terbangunnya cenderung datar dan tidak berbatasan dengan rona alam yang ekstrem. Pola permukiman yang terwujud pada permukiman masyarakat Bali Aga Desa Pakraman Timbrah dominan dipengaruhi oleh faktor sosio kultural yaitu sistem kepercayaan dan tradisi yang mengakar kuat dan masih ajeg dilaksanakan sampai saat ini. Jika dilihat dalam perkembangannya, pola permukiman yang ada saat ini tidak dapat dilepaskan sebagai hasil dari keseluruhan rangkaian proses hubungan antara manusia dan lingkungan yang melibatkan nilai sosio kultural sebagai dasar utama namun juga tidak terlepas dari perilaku, proses dan pemahaman terhadap lingkungan itu sendiri yang meliputi kebutuhan akan ruang pribadi dan kewilayahan serta persepsi dan penilaian terhadap lingkungan yang mendorong terjadinya perkembangan atau perubahan atau transformasi dari perwujudan (pola-pola) yang ada ke arah yang (dirasa) lebih baik.

\section{Kesimpulan}

Dari studi yang dilakukan berkaitan dengan transformasi permukiman Bali Aga di Desa Timbrah, Karangasem, dapat disimpulkan bahwa:

- Rumah dan pola permukiman menggambarkan keseluruhan rangkaian proses hubungan antara manusia dan lingkungan yang melibatkan nilai sosio kultural sebagai dasar utama. Transformasi atau perubahan didasari atas motivasi untuk mewujudkan kualitas yang (dirasa) lebih baik.

- Proses transformasi pada rumah tinggal dan pola spasial di Desa Timbrah berjalan secara perlahan dengan tetap mereferensi pada sistem nilai atau kearifan - kearifan lokal yang ada.

- Transformasi yang terjadi pada rumah tinggal dan pola spasial pada dasarnya terjadi akibat meningkatnya kebutuhan akan ruang yang didorong oleh berkembangnya keluarga-keluarga, perubahan gaya hidup dimana keluarga ingin mandiri menjadi keluarga inti, hal ini mempercepat berkembangnya rumah baru pada área-area yang baru. Selain itu terdapat pula kebutuhan untuk ekspresi diri yang diwujudkan dengan melakukan perubahan terhadap rumahnya dengan memanfaatkan perkembangan teknologi dalam bahan bangunan, ataupun akomodasi atas ekspresi kehidupan modern seperti akses dan kepemilikan kendaraan roda empat.

\section{Daftar Pustaka}

Alexander, C. (1987). A New Theory of Urban Design. USA: Oxford University Press. Altman, I. (1989). Culture and Environment. Cambridge: Cambridge University Press. 
Departemen Pendidikan dan Kebudayaan. (1985). Arsitektur Tradisional Daerah Bali. Departemen Pendidikan dan Kebudayaan Propinsi Bali

Desa Adat Timbrah. (1989). Awig-awig Desa Adat Timbrah Kecamatan Karangasem Kabupaten Daerah Tingkat II Karangasem

Hauser-Schäublin, B., \& Ardika, I. W. (Eds.). (2008). Burials, Texts and Rituals: Ethnoarchaeological Investigations in North Bali, Indonesia (Vol. 1 Göttinger Beiträge zur Ethnologie). Göttingen: Universitätsverlag Göttingen.

Kusumawati, L., Topan, M. A., Winandari, M. I. R., \& Sofian, I. (2014). Jejak Megalitik Arsitektur Tradisional Sumba. Yogyakarta: Graha Ilmu.

Pangarsa, G. W. (2006). Merah Putih Arsitektur Nusantara. Yogyakarta: Penerbit Andi.

Parimin, A. P. (1986). Fundamental Study on Spatial Formation of Island Village: Environmental Hierarchy of Sacred-Profane Concept in Bali. (Doctoral dissertation), University of Osaka, Japan.

Patra, M. S. (1992). Hubungan Seni Bangunan dengan Hiasan dalam Rumah Tinggal Adati Bali. Jakarta: Balai Pustaka.

PemerintahRI. (2011). Undang-undang Republik Indonesia No. 1 Tahun 2011, tentang Perumahan dan Kawasan Permukiman. RI, P. Jakarta: Pemerintah RI

Poerwadarminta, W.J.S. (1982). Kamus Umum Bahasa Indonesia. Jakarta: Balai Pustaka.

Rapoport, A. (1969). House Form and Culture: Foundations of Cultural Geography Series (P. R. Wagner Ed.). Englewood Cliffs, New Jersey: Prentice-Hall Inc.

Rapoport, A. (1983). Development, Culture Change and Supportive Design. Habitat International 7(5-6): 249-268.

Reuter, T. A. (2002). Custodians of the Sacred Mountains: Culture and Society in the Highlands of Bali. Honolulu: University of Hawaii Press.

Ronald, A. (2005). Nilai-nilai Arsitektur Rumah Tradisional Jawa. Yogyakarta: Gadjah Mada University Press.

Schaaremann, D. (1986). Tatulingga: Tradition and Continuity, an Investigation in Ritual and Social Organization in Bali. Basel: Kommision bei Wepf \& Co. AG Verlag.

Sesotyaningtyas, M., Pratiwi, W.D., dan Setyono, J.S. (2015). Transformasi Hunian dengan Perspektif Spasial dan Tatanan Budaya : Komparasi Permukiman Kumuh Bang Bua, Thailand dan Kampung Naga, Indonesia. Geoplanning: Journal of Geomatics and Planning, 2(2), 116-123.

Suacana, W. G. (2011). Budaya Demokrasi dalam Kehidupan Masyarakat Desa di Bali. JURNAL KAJIAN BALI, 01(01), 88-151.

Suada, I N. (2003). Beberapa Desa Unik di Bali. Dinas Kebudayaan Propinsi Bali

Suryabrata, S. (1997). Metodologi Penelitian. Jakarta: PT Raja Grafindo Persada

Swanendri, N. M., \& Dewi, N. K. A. (2010). Rancangan Rumah Tumbuh tipe 36 dan 45 di Kota Denpasar. (Laporan Akhir Penelitian Hibah Bersaing Tahun Ke-2). Denpasar: Universitas Udayana.

Swanendri, N. M., \& Setiada, I. N. K. (2015). Menemukenali Arsitektur Rumah Tinggal Masyarakat Bali Aga di Desa Pakraman Timbrah Desa Pertima Kecamatan Karangasem Kabupaten Karangasem (Laporan Akhir Penelitian Hibah Penelitian Unggulan Program Studi (HUPS) Tahun 2015). Denpasar: Universitas Udayana.

Swanendri, N. M. (2016). Eksistensi Tradisi Bali Aga pada Arsitektur Rumah Tinggal di Desa Pakraman Timbrah, Karangasem. Jurnal Ruang-Space, 3(2), 145-156.

Swanendri, N. M., \& Setiada, I. N. K. (2016). Pola Spasial Permukiman Masyarakat Bali Aga di Desa Pakraman Timbrah, Desa Pertima, Kecamatan Karangasem, Kabupaten Karangasem (Laporan Akhir Penelitian Hibah Penelitian Unggulan Program Studi (HUPS) Tahun 2016). Denpasar: Universitas Udayana. 
Swanendri, N. M. (2017). Pola Spasial Permukiman Desa Pakraman Timbrah, Karangasem. Jurnal Ruang-Space, 4(1), 93-108.

Yusuf, A. M. (2014). Metode Penelitian: Kuantitatif, Kualitatif, dan Penelitian Gabungan. Jakarta: Prenadamedia Group. 